\title{
Artikel
}

\section{De rechtspositie van de raadsman tijdens het politieverhoor}

Mr. J.H.J. (Joost) Verbaan en mr. L.E. (Laura) Hollander*

NTS 2020/4

\section{Inleiding}

Op 27 november 2018 heeft het EHRM in de zaak Soytemiz/Turkije een opvallend arrest gewezen met betrekking tot de invulling van het recht op verhoorbijstand. Het EHRM oordeelt dat het recht op verhoorbijstand niet enkel de aanwezigheid van de raadsman bij het politieverhoor inhoudt, maar spreekt met zoveel woorden uit dat het de raadsman dient te worden toegestaan zich actief in de verdediging op te stellen. ${ }^{1}$ In Nederland is de rechtspositie van de raadsman tijdens het politieverhoor hoofdzakelijk neergelegd in het Besluit inrichting en orde politieverhoor (hierna: het Besluit). ${ }^{2}$ Hierin is bepaald dat de raadsman alleen direct na aanvang en direct voor afloop van het politieverhoor bevoegd is om opmerkingen te maken of vragen te stellen. ${ }^{3}$ Gedurende het verhoor kan - volgens het Besluit - de raadsman de

Mr. J.H.J. Verbaan is wetenschappelijk docent en onderzoeker bij de afdeling Strafrecht aan de Erasmus Universiteit Rotterdam. Mr. L.E. Hollander was tot voor kort verbonden aan de Erasmus Universiteit als student-assistent en deed in het kader van haar master Strafrecht onderzoek naar de rechtspositie van de raadsman tijdens het politieverhoor. Zij rond momenteel de master Toga aan de Maas (EUR) af en is student-stagiaire bij Hertoghs Advocaten.

1. EHRM 27 november 2018, ECLI:CE:ECHR:2018:1127JUD005783709, par. 44-45 (Soytemiz/Turkije).

2. Besluit van 26 januari 2017 , houdende regels voor de inrichting van en de orde tijdens het politieverhoor waaraan de raadsman deelneemt (Stb. 2017, 29) (hierna: het Besluit).

3. Zie art. 5 lid 2 Besluit. verhorend ambtenaar erop opmerkzaam maken dat de verdachte een hem gestelde vraag niet begrijpt, dat de verhorend ambtenaar het pressieverbod niet in acht neemt en dat de fysieke of psychische toestand van de verdachte zodanig is dat deze een verantwoorde voortzetting van het verhoor verhindert. ${ }^{4}$ De recente jurisprudentie van het EHRM maakt de vraag of de in het Besluit neergelegde rechtspositie van de raadsman tijdens het politieverhoor in Nederland niet te beperkt is uitgelegd, weer actueel. Met andere woorden: is het Besluit (nog) wel EHRM-proof?

Eerder is door Dieben en Van 't Hullenaar ingegaan op (de temporele reikwijdte van) het recht op verhoorbijstand in Nederland. ${ }^{5}$ In dit artikel spitsen wij ons toe op de rechtspositie van de raadsman tijdens het politieverhoor. Daartoe wordt eerst het geldend wettelijk kader uiteengezet, waarbij in het bijzonder het Besluit wordt besproken (par. 2). Daarna wordt aandacht besteed aan de invulling die het EHRM geeft aan het recht op rechtsbijstand, zoals dat voortvloeit uit artikel 6 EVRM (par. 3). Vervolgens wordt een vergelijking gemaakt tussen de rechtspositie die de raadsman heeft volgens het Besluit en de rechtspositie zoals het EHRM die heeft ingevuld (par. 4). Het artikel wordt afgesloten met een conclusie (par. 5).

\section{Het wettelijk kader}

Gelet op het onderwerp van dit artikel en de lange geschiedenis van het recht op rechtsbijstand, voert het

4. Zie art. 6 Besluit.

5. Th.O.M. Dieben \& S.F.W. van 't Hullenaar, 'De zaak van Van de Kolk tegen Nederland', TPWS 2019/63, p. 152-155. 
te ver om uitvoerig in te gaan op de ontwikkeling van het recht op rechtsbijstand. ${ }^{6}$ Desondanks menen wij dat het huidig wettelijke kader omtrent de rechtspositie van de raadsman tijdens het politieverhoor niet kan worden besproken zonder enige aandacht te schenken aan de achtergrond hiervan (par. 2.1). Wij staan met name stil bij Richtlijn 2013/48/EU (hierna: de Richtlijn), ${ }^{7}$ aangezien de inhoud daarvan een belangrijke bijdrage heeft geleverd aan de invulling van het recht op rechtsbijstand in Nederland (par. 2.2). Daarna komt het huidige wettelijk kader, in het bijzonder het Besluit, aan bod (par. 2.3).

\subsection{Achtergrond}

Met de komst van de arresten Salduz/Turkije en Panovits/Cyprus is voor Nederland in 2009 het startschot gegeven om het recht op rechtsbijstand (minimalistisch) te erkennen. De Hoge Raad gaat akkoord met de erkenning van het recht op consultatiebijstand aan meerderjarige verdachten. Enkel minderjarige verdachten krijgen daarnaast ook het recht om een raadsman fysiek aanwezig te laten zijn bij het politieverhoor. ${ }^{8}$ De wetgever is in reactie hierop aan de slag gegaan met het concipiëren van een conceptwetsvoorstel. In afwachting van de behandeling van deze conceptwet is de door de Hoge Raad gegeven uitleg van artikel 6 EVRM gecodificeerd in de Aanwijzing rechtsbijstand politieverhoor (hierna: de Aanwijzing). ${ }^{9}$ Uit de inhoud van de Aanwijzing blijkt de terughoudende opstelling van de wetgever als het gaat om het toelaten van de raadsman bij het verhoor. ${ }^{10}$ Bovendien dient de raadsman zich in de gevallen waarin hij aanwezig is, zoals bij het politieverhoor van een minderjarige verdachte, terughoudend op te stellen. De raadsman dient erop toe te zien dat geen ongeoorloofde druk op de verdachte wordt uitgeoefend en dat de verdachte alle vragen begrijpt. Het verhoor mag door de

6. Zie hiervoor onder meer T.N.B.M. Spronken, Verdediging (diss. Maastricht), Deventer: Gouda Quint 2001; C.J.C.F. Fijnaut, De toelating van raadslieden tot het politiële verdachtenverhoor, Antwerpen/Arnhem: Kluwer/Gouda Quint 1987; C.J.C.F. Fijnaut, 'De toelating van de raadsman tot het politiële verdachtenverhoor. Een status questionis op de drempel van de eenentwintigste eeuw', in: M.S. Groenhuijsen \& G. Knigge (red.), Het vooronderzoek in strafzaken. Tweede interimrapport onderzoeksproject Strafvordering 2001, Deventer: Gouda Quint 2001; L. Stevens \& W. Verhoeven, Raadsman bij politieverhoor. Invloed van voorafgaande consultatie en aanwezigheid van raadslieden op de organisatie en wijze van verhoren en de proceshouding van verdachten, Den Haag: Boom Juridische uitgevers 2010.

7. Richtlijn 2013/48/EU van het Europees Parlement en de Raad van 22 oktober 2013 betreffende het recht op toegang tot een advocaat in strafprocedures en in procedures ter uitvoering van een Europees aanhoudingsbevel en het recht om een derde op de hoogte te laten brengen vanaf de vrijheidsbeneming en om met derden en consulaire autoriteiten te communiceren tijdens de vrijheidsbeneming ( $P b E U$ L294).

8. HR 30 juni 2009, ECLI:NL:HR:2009:BH3079, NJ 2009/349 m.nt. T.M. Schalken; HR 30 juni 2009, ECLI:NL:HR:2009:BH3081, NJ 2009/350; HR 30 juni 2009, ECLI:NL:HR:2009:BH3084, NJ 2009/351 m.nt. T.M. Schalken.

9. Aanwijzing rechtsbijstand politieverhoor, Stcrt. 2010, 4003

10. P.A.M. Mevis \& J.H.J. Verbaan, 'Legal assistance and police interrogation (Problematic aspects of) Dutch criminal procedure in relation to European Union and the Council of Europe', Erasmus Law Review 2014, afl. 4, p. 175-190 raadsman niet worden gehinderd. ${ }^{11}$ Het schenden van deze regels betekent dat de raadsman, na overleg met de officier van justitie, kan worden bevolen de verhoorruimte te verlaten. Hiermee wordt getracht de voortgang van het politieverhoor zo min mogelijk te hinderen dan wel te beïnloeden. De nadruk blijft dus liggen op het vlotte verloop van het verhoor.

Het conceptwetsvoorstel wordt uiteindelijk in 2011 gepubliceerd. $^{12}$ In het conceptwetsvoorstel wordt het recht op verhoorbijstand voor meerderjarige verdachten neergelegd in artikel 28b Sv. Dit recht is niet absoluut: het recht op verhoorbijstand voor een meerderjarige verdachte is beperkt tot de verdenking van strafbare feiten waarop een gevangenisstraf van zes jaren of meer is gesteld en voor zover het belang van het onderzoek verhoorbijstand toelaat. ${ }^{13}$ De verdere invulling van de rechtsbijstand of de rechtspositie van de raadsman is in het wetsvoorstel niet geregeld.

In diezelfde periode lijken de uitspraken van het EHRM er meer en meer op te wijzen dat het recht op rechtsbijstand ongeclausuleerd moet worden erkend. ${ }^{14}$ Bovendien spoort de door het EHRM gegeven uitleg van artikel 6 lid 3 sub c EVRM de Europese Unie aan om in 2013 het recht op rechtsbijstand in een richtlijn op te nemen, zodat in elke lidstaat eenzelfde regeling komt te gelden omtrent het recht op rechtsbijstand. ${ }^{15}$ De Europese Unie vreest dat lidstaten zonder juiste implementatie van de rechtspraak van het EHRM het risico lopen aanzienlijke kosten te maken die voortvloeien uit de toegekende schadevergoedingen van succesvolle klagers bij het EHRM. ${ }^{16}$

11. Het is dan ook verplicht de mobiele telefoon uit te schakelen, op de plaats te blijven zitten en niet hoorbaar en zichtbaar andere werkzaamheden uit te voeren.

12. Wijziging van het Wetboek van Strafvordering tot aanvulling van de regeling van het politieverhoor van de verdachte, diens aanhouding en voorgeleiding aan de officier van justitie, de inverzekeringstelling en het recht op rechtsbijstand in het strafproces (Wet rechtsbijstand en politieverhoor), concept 22 maart 2011. Te raadplegen via: https:// www.internetconsultatie.nl/rechtsbijstandpolitieverhoor/document/ 318.

13. Zie art. 28b conceptwetsvoorstel Wet rechtsbijstand en politieverhoor van 22 maart 2011.

14. EHRM 24 september 2009, ECLI:CE:ECHR:2009:0924JUD000702504, par. 78-79, NJ 2010/91 m.nt. J.M. Reijntjes (Pishchalnikov/Rusland); EHRM 13 oktober 2009, ECLI:CE:ECHR:2009:1013JUD000737703, par. 32-34 (Dayanan/Turkije); EHRM 9 februari 2010, ECLI:CE:ECHR: 2010:0209JUD000203904, par. 33-36 (Boz/Turkije); EHRM 14 oktober 2010, ECLI:CE:ECHR:2010:1014JUD000146607, par. 45 en 54-55, NJ 2011/386 m.nt. T.M. Schalken (Brusco/Frankrijk); EHRM 28 juni 2011, ECLI:CE:ECHR:2011:0628JUD000442909, par. 256-257 (Šebalj/Kroatië); EHRM 24 oktober 2013, ECLI:CE:ECHR: 2013:1024JUD006288011, par. 81-85 (Navone e.a./Monaco).

15. Zie overweging 12 in de preambule van de Richtlijn.

16. Voorstel voor een richtlijn van het Europees Parlement en de Raad betreffende het recht op toegang tot een advocaat in strafprocedures en betreffende het recht op communicatie bij aanhouding, $\operatorname{COM}(2011) 326$ final, overweging 13. Te raadplegen via: http:// ec.europa.eu/transparency/regdoc/? fuseaction=list \& coteld $=1$ \&year=2011\&number=326\&version=ALL\&lan guage=en. 
2.2 Richtlijn en Nederlandse uitwerking daarvan Conform artikel 1 Richtlijn bevat de Richtlijn minimumvoorschriften voor verdachten om toegang te hebben tot een raadsman. De bepaling van artikel 2 Richtlijn geeft weer dat deze van toepassing is op verdachten vanaf het moment waarop zij door de autoriteiten op de hoogte zijn gesteld van de verdenking van een strafbaar feit. Het recht op bijstand van een raadsman is neergelegd in het derde artikel van de Richtlijn. Iedere verdachte kan aanspraak maken op consultatiebijstand (art. 3 lid 2 en 3 sub a Richtlijn) en verhoorbijstand (art. 3 lid 3 sub b Richtlijn). Tijdens het verhoor dient de raadsman daadwerkelijk aan het verhoor te kunnen deelnemen, overeenkomstig de procedures in het nationale recht. Nationale procedures mogen niet aan de daadwerkelijke uitoefening en de essentie van dit recht in de weg staan, zo volgt uit overweging 25 in de preambule van de Richtlijn. In deze overweging is tevens neergelegd dat de raadsman tijdens het verhoor vragen kan stellen, verduidelijking kan vragen en verklaringen kan afleggen. Dit lijkt te impliceren dat de raadsman zich actief mag opstellen tijdens het politieverhoor; naast de verdachte zitten en een passieve houding innemen is volgens de Richtlijn niet (meer) aan de orde.

Evident is dat de eerdere Nederlandse invulling van het recht op rechtsbijstand, zoals neergelegd in het conceptwetsvoorstel en de Aanwijzing, niet meer voldoet. Nederland heeft de verplichting de Richtlijn binnen drie jaar te implementeren. De Hoge Raad die in 2014 nog stellig oordeelt dat het de rechtsvormende taak van de Hoge Raad te buiten gaat om, in reactie op de Richtlijn en de rechtspraak van het EHRM, een algemene regeling op te stellen over het recht op rechtsbijstand, ${ }^{17}$ gaat eind 2015 'om'. Met het arrest van eind december 2015 kent de Hoge Raad aan iedere aangehouden verdachte zowel het recht op consultatiebijstand als het recht op verhoorbijstand toe. ${ }^{18}$ Enige kanttekening daarbij is dat de Hoge Raad daar pas vanaf maart 2016 consequenties aan gaat verbinden. ${ }^{19}$ Het conceptwetsvoorstel wordt van tafel geveegd en wordt gesplitst in twee nieuwe wetsvoorstellen ter implementatie van de Richtlijn. De nieuwe regeling wordt aangenomen en op 1 maart 2017 (net niet binnen de door de Richtlijn gestelde termijn) treedt deze wetgeving in werking. ${ }^{20}$

17. HR 1 april 2014, ECLI:NL:HR:2014:770, NJ 2014/268 m.nt. T.M. Schalken, r.o. 2.5.4.

18. HR 22 december 2015, ECLI:NL:HR:2015:3608, NJ 2016/52 m.nt. A.H. Klip.

19. Zie meer hierover in Th.O.M. Dieben \& S.F.W. van 't Hullenaar, 'De zaak van Van de Kolk tegen Nederland', TPWS 2019/63, p. 152-155.

20. Wet van 17 november 2016, houdende implementatie van richtlijn $\mathrm{nr}$. 2013/48/EU van het Europees Parlement en de Raad van 22 oktober 2013 betreffende het recht op toegang tot een advocaat in strafprocedures en in procedures ter uitvoering van een Europees aanhoudingsbevel en het recht om een derde op de hoogte te laten brengen vanaf de vrijheidsbeneming en om met derden en consulaire autoriteiten te communiceren tijdens de vrijheidsbeneming (PbEU L294) (Stb. 2016, 475) en Wet van 17 november 2016, houdende wijziging van het Wetboek van Strafvordering en enige andere wetten in verband met aanvulling van bepalingen over de verdachte, de raadsman en enkele dwangmiddelen (Stb. 2016, 476).
Die regeling is thans nog steeds het geldende wettelijk kader.

\subsection{Huidige wet- en regelgeving}

De huidige regeling biedt in artikel $28 \mathrm{~Sv}$ de verdachte het recht zich te laten bijstaan door een raadsman. Op grond van artikel 28a Sv kan hij hier vrijwillig en ondubbelzinnig afstand van doen. Het recht op consultatiebijstand is neergelegd in artikel 28c Sv en conform artikel $28 \mathrm{~d} \mathrm{~Sv}$ heeft de verdachte het recht om een raadsman fysiek aanwezig te laten zijn bij het politieverhoor. De plicht om de verdachte voorafgaand aan het eerste politieverhoor hierover te informeren, volgt uit artikel 27c lid 3 Sv. Volgens de Hoge Raad is dit vanaf het moment dat de politie aan een aangehouden verdachte vragen gaat stellen die betrekking hebben op diens betrokkenheid bij een strafbaar feit waarvan hij wordt verdacht. ${ }^{21}$ Ingeval nog geen sprake is van een vermeend strafbaar feit, kan het wel zo zijn dat jegens de verdachte een redelijk vermoeden van schuld bestaat. Ook onder deze omstandigheid kan sprake zijn van een verhoorsituatie. ${ }^{22}$ Wanneer sprake is van een verhoorsituatie moet derhalve niet beperkt worden uitgelegd.

De rechtspositie van de raadsman tijdens het politieverhoor is conform artikel $28 \mathrm{~d}$ lid $4 \mathrm{~Sv}$ vormgegeven in het Besluit. De raadsman neemt zo veel mogelijk plaats naast de verdachte, zo volgt uit artikel 3 Besluit, en mag, tenzij hij hiervoor toestemming heeft gekregen van de verhoorder(s) en de verdachte, namens de verdachte geen vragen beantwoorden (art. 4 Besluit). Artikel 5 lid 1 Besluit stelt dat hij opmerkingen en verzoeken tot de verhoorder(s) dient te richten en het tweede lid van dat artikel bepaalt dat de gelegenheid tot vragen stellen beperkt is tot het moment direct na aanvang en direct voor afloop van het politieverhoor. Gedurende het politieverhoor is de raadsman bevoegd de verhoorder erop opmerkzaam te maken dat de verdachte een gestelde vraag niet begrijpt, dat de verhoorder het pressieverbod niet in acht neemt en dat de fysieke of psychische toestand van de verdachte ertoe leidt dat een verantwoorde voortzetting van het verhoor wordt verhinderd (art. 6 Besluit). Artikel 7 lid 1 Besluit beperkt dat recht in die zin dat de raadsman niet buiten deze bevoegdheden mag treden en geen onredelijk gebruik daarvan mag maken. Het verstoren van de orde van het politieverhoor is niet toegelaten. In dit kader mag de raadsman wel aantekeningen maken tijdens het verhoor, maar het maken van opnamen mag niet (art. 7 lid 2 en 3 Besluit). Artikel 8 Besluit bepaalt dat de raadsman de verhoorruimte moet verlaten indien de raadsman in strijd met artikel 4, 5 lid 1 of 7 Besluit handelt en hij daarover tevergeefs is gewaarschuwd. $\mathrm{Na}$ verwijdering van de raadsman kan het verhoor slechts worden voortgezet als de raadsman weer wordt toegelaten tot de verhoorruimte, de verdachte alsnog afstand doet van zijn recht op rechts-

21. HR 6 november 2018, ECLI:NL:HR:2018:2056, NJ 2019/309 m.nt. T. Kooijmans.

22. HR 6 november 2018, ECLI:NL:HR:2018:2056, NJ 2019/309 m.nt. T. Kooijmans, r.o. 2.3.2. 
bijstand of een vervangende raadsman beschikbaar is (art. 8 lid 2 Besluit).

\section{De invulling van de rechtspositie van de raadsman door het EHRM}

Het EHRM heeft met zijn jurisprudentie omtrent artikel 6 lid 3 sub c EVRM een sterke bijdrage geleverd aan de ontwikkeling van het recht op rechtsbijstand in Nederland. Allereerst worden enkele recente uitspraken besproken, waarin door het EHRM het toetsingskader van een schending van artikel 6 EVRM wegens het ontbreken van rechtsbijstand uiteen wordt gezet (par. 3.1). Vervolgens wordt ingegaan op het arrest Soytemiz/Turkije, waarin het EHRM de rechtspositie van de raadsman tijdens het politieverhoor nader duidt (par. 3.2).

\subsection{Toetsingskader artikel 6 EVRM}

Het EHRM heeft in de zaak Salduz/Turkije een concreet toetsingskader ontwikkeld voor het aannemen van een schending van artikel 6 EVRM bij het ontbreken van rechtsbijstand in de voorfase van het onderzoek. Het EHRM oordeelt dat uit artikel 6 EVRM voortvloeit dat een verdachte recht heeft op rechtsbijstand vanaf het eerste politieverhoor. Afwijking daarvan kan enkel op basis van dwingende redenen. Indien de verdachte geen gebruik heeft kunnen maken van zijn recht op rechtsbijstand, maar wel een belastende verklaring heeft afgelegd die vervolgens is gebruikt voor het bewijs, is sprake van een onherstelbare aantasting van zijn rechten en is sprake van een schending van artikel 6 EVRM. ${ }^{23}$

In de zaak Ibrahim e.a./Verenigd Koninkrijk wordt dit toetsingskader gerelativeerd. ${ }^{24} \mathrm{Er}$ wordt een 'tweestappentoets' geïntroduceerd die volgens het EHRM voortvloeit uit de kernoverweging van Salduz/Turkije. ${ }^{25}$ Als eerste stap dient te worden onderzocht of dwingende redenen bestaan voor de beperking op het recht op bijstand van een raadsman. Een beperking van het recht op toegang tot rechtsbijstand is alleen toegestaan in uitzonderlijke omstandigheden. Daarnaast dient de beperking van tijdelijke aard te zijn en moet de beperking op een individuele beoordeling van de bijzondere omstandigheden van het geval zijn gebaseerd. Bij het beoordelen van de door de autoriteiten gestelde dwingende redenen, is van belang dat de beslissing tot de beperking van het recht zijn basis vindt in het nationale recht. Tevens dient de reikwijdte en inhoud van de beperking voldoende omschreven te zijn in het nationale recht ter

23. EHRM (Grote Kamer) 27 november 2008, ECLI:CE:ECHR: 2008:1127JUD003639102, par. 55, NJ 2009/214 (Salduz/Turkije).

24. EHRM (Grote Kamer) 13 september 2016, ECLI:CE:ECHR: 2016:0913JUD005054108, NJ 2017/452 m.nt. P.H.P.H.M.C. van Kempen (Ibrahim e.a./Verenigd Koninkrijk).

25. EHRM (Grote Kamer) 13 september 2016, ECLI:CE:ECHR 2016:0913JUD005054108, par. 257-274, NJ 2017/452 m.nt. P.H.P.H.M.C. van Kempen (Ibrahim e.a./Verenigd Koninkrijk). begeleiding van de nationale autoriteiten die de beslissing tot beperking nemen. Indien de autoriteiten overtuigend hebben aangetoond dat een dringende noodzaak bestaat om ernstige nadelige gevolgen voor het leven, de vrijheid of de fysieke integriteit te voorkomen, kan dit resulteren in dwingende redenen om het recht op bijstand van een raadsman te beperken.

Als tweede stap moet worden geëvalueerd of de procedure in zijn geheel eerlijk is verlopen. Het ontbreken van dwingende redenen vormt daarmee op zichzelf geen grond om een schending van artikel 6 EVRM aan te nemen. Dit wil niet zeggen dat de uitkomst van de eerste stap niet van belang is bij de beoordeling of sprake is van een eerlijk proces. In het geval geen dwingende redenen voor beperking van toegang tot een raadsman bestaan, controleert het EHRM de toepassing van de beperking zeer strikt. Bij het beoordelen van de eerlijkheid van de gehele strafprocedure weegt het niet (kunnen) aantonen van dwingende redenen voor de beperking door de nationale autoriteiten mee in hun nadeel. Indien wel sprake is van dwingende redenen, dient holistisch te worden getoetst of het strafproces eerlijk is verlopen, zoals bedoeld in artikel 6 lid 1 EVRM. Al met al is het dus vooral de tak van de nationale autoriteiten om overtuigend aan te tonen dat in een specifiek geval sprake is van exceptionele omstandigheden, waardoor de beperking niet leidt tot een onherstelbare schending van het recht op een eerlijk proces. Het EHRM somt tien niet-uitputtende aanknopingspunten op die kunnen worden meegenomen in de weging van de tweede stap. Belangrijke aanknopingspunten zijn onder meer de kwetsbaarheid van de verdachte door zijn leeftijd en/of mentale capaciteit en de mogelijkheid om gedurende de strafzaak het bewijs te betwisten.

Het toetsingskader uit Ibrahim e.a./Verenigd Koninkrijk is eveneens toegepast in Beuze/België. ${ }^{26}$ Deze zaak maakt duidelijk dat het toetsingskader niet alleen geldt voor een 'ticking bom'-situatie zoals in Ibrahim e.a./ Verenigd Koninkrijk, maar eerder kan worden beschouwd als algemeen toetsingskader voor het beoordelen van een eventuele schending van artikel 6 EVRM. Daarbij wordt geoordeeld dat een praktische en effectieve uitoefening van het recht op rechtsbijstand vereist dat een verdachte het recht heeft op de fysieke aanwezigheid van een raadsman bij het politieverhoor. ${ }^{27}$ Daarmee is een gedeelte van de vraag over de precieze invulling van het recht op rechtsbijstand beantwoord.

\subsection{Soytemiz/Turkije}

In de hierboven besproken arresten gaat het EHRM met name in op de invulling van het recht op rechtsbijstand. Het staat thans buiten kijf dat een verdachte aan artikel 6 EVRM het recht op consultatiebijstand en verhoorbij-

26. EHRM (Grote Kamer) 9 november 2018, ECLI:CE:ECHR 2018:1109JUD007140910, NJ 2019/15 m.nt. W.H. Vellinga (Beuze/ België).

27. EHRM (Grote Kamer) 9 november 2018, ECLI:CE:ECHR: 2018:1109JUD007140910, par. 131-136, NJ 2019/15 m.nt. W.H. Vellinga (Beuze/België). 
stand kan ontlenen. Over de rechtspositie van de raadsman tijdens de verhoorbijstand heeft het EHRM zich zelden uitgelaten. Daarom is de zaak Soytemiz/Turkije opmerkelijk te noemen. In deze zaak was Soytemiz aangehouden wegens het bieden van hulp aan een verboden politieke partij. Voorafgaand aan zijn verhoor heeft hij met een raadsman kunnen overleggen. Ook tijdens het politieverhoor is de raadsman aanwezig. Soytemiz wordt op enig moment tijdens het politieverhoor door zijn raadsman op zijn zwijgrecht gewezen. Daarnaast verzoekt de raadsman de politieambtenaren een deel van de verklaring van Soytemiz uit het proces-verbaal te schrappen. Deze gebeurtenissen leiden tot de verwijdering van de raadsman door de politieambtenaren uit de verhoorruimte. Soytemiz stelt dat hij, nadat zijn raadsman uit de verhoorruimte is gezet, is gedwongen een belastende verklaring te ondertekenen. Die verklaring is vervolgens gebezigd voor de veroordeling. Soytemiz klaagt dat door het verwijderen van zijn raadsman tijdens het verhoor en het gebruiken van de nadien ondertekende belastende verklaring voor het bewijs in strijd met artikel 6 lid 3 sub c EVRM is gehandeld.

Voorafgaand aan de toetsing van de feiten in de zaak, overweegt het EHRM dat eenieder die is aangehouden recht heeft op bijstand van een raadsman. De fysieke aanwezigheid van een raadsman gedurende het politieverhoor waarborgt de effectieve uitoefening van de rechten in artikel 6 lid 3 sub c EVRM. Vervolgens geeft het Hof in Straatsburg nader invulling aan het recht op bijstand door een raadsman:

'Therefore, the right to be assisted by a lawyer requires not only that the lawyer is permitted to be present, but also that he is allowed to actively assist the suspect during, inter alia, the questioning by the police and to intervene to ensure respect for the suspect's rights $(. .$.$) as a person charged with a criminal$ offence should be able to obtain the whole range of services specifically associated with legal assistance, not only in the course of trial but also during the pretrial stage given its particular importance for the preparation of the criminal proceedings. ${ }^{28}$

Het gaat dus niet slechts om de aanwezigheid bij het verhoor, maar om actieve bijstand van de fysiek aanwezige raadsman. Dat recht kan worden uitgeoefend vanaf de aanvang van het politieverhoor tot en met het einde daarvan, hetgeen ook het voordragen van de verklaring en het tekenen van het proces-verbaal omvat. Het EHRM benadrukt nog eens dat deze houding van een advocaat bij een effectieve uitoefening van het recht op rechtsbijstand past. Naast het feit dat het recht op verhoorbijstand evident blijkt, wordt door het EHRM met zoveel woorden geconcludeerd dat de raadsman gedurende het politieverhoor een actieve houding mag innemen en mag ingrijpen om de rechten van de verdachte te beschermen.

28. EHRM 28 november 2018, ECLI:CE:ECHR:2018:1127JUD005783709, par. 44 (Soytemiz/Turkije). Cursivering door auteurs.
Met betrekking tot de zaak stelt het EHRM de situatie dat de raadsman uit de verhoorruimte wordt verwijderd gelijk aan de situatie waarin iemand geen bijstand van een raadsman heeft gehad. Het eerder genoemde toetsingskader uit Ibrahim e.a./Verenigd Koninkrijk brengt het EHRM tot de conclusie dat de nationale autoriteiten onvoldoende hebben aangetoond dat dwingende redenen bestaan die de beperking van het recht op bijstand van een raadsman rechtvaardigen. Het EHRM neemt in die overweging mee dat de verwijdering van de raadsman geen grondslag heeft in de Turkse nationale weten regelgeving en dat de politieambtenaren in kwestie hiervoor ook zijn veroordeeld. ${ }^{29}$ Ten tweede overweegt het EHRM dat de strafprocedure in zijn geheel niet eerlijk is verlopen, angezien de (na verwijdering van de raadsman) ondertekende verklaring voor het bewijs is gebezigd, zonder dat voldoende onderzoek is gedaan naar de betrouwbaarheid en rechtmatigheid daarvan. Er wordt in dit geval dan ook geoordeeld dat sprake is van een schending van artikel 6 lid 3 sub c EVRM.

\section{Vergelijking}

In paragraaf 2 en 3 van deze bijdrage is vanuit nationaal en Europees perspectief ingegaan op de rechtspositie van de raadsman tijdens het politieverhoor. In deze paragraaf worden deze twee perspectieven met elkaar vergeleken. Allereerst wordt aandacht geschonken aan de Nederlandse interpretatie van het arrest $\operatorname{Van} d e$ Kolk/Nederland, ${ }^{30}$ die volgt uit het recente arrest van de Hoge Raad van 17 december 2019 (par. 4.1). ${ }^{31}$ Vervolgens wordt toegespitst op de rechtspositie van de raadsman tijdens het politieverhoor door het Besluit te toetsen aan de invulling die het EHRM geeft aan artikel 6 lid 3 sub c EVRM (par. 4.2).

\subsection{De toepasselijkheid van het recht op verhoorbijstand}

Op 28 mei 2019 heeft het EHRM uitspraak gedaan in Van de Kolk/Nederland. Van de Kolk werd in 2009 verdacht van het verspreiden van kinderporno. Tegen de wens van Van de Kolk in was geen raadsman aanwezig tijdens het politieverhoor, omdat dit niet in de toen geldende regelgeving (de Aanwijzing) was geregeld. In de Aanwijzing wordt het recht op verhoorbijstand immers slechts aan minderjarige verdachten toegekend. Volgens het EHRM levert het ontbreken van een wettelijke regeling met betrekking tot het recht op verhoorbijstand voor de meerderjarige verdachte geen dwingende reden op voor beperking van dit algemeen erkende recht. Aangezien de Nederlandse autoriteiten geen argumenten hebben aangedragen waarom Van de Kolk door deze beperking niet is beroofd van zijn recht op een eerlijk

29. EHRM 28 november 2018, ECLI:CE:ECHR:2018:1127JUD005783709, par. 48-51 (Soytemiz/Turkije).

30. EHRM 28 mei 2019, ECLI:CE:ECHR:2019:0528JUD002319215 (Van de Kolk/Nederland).

31. HR 17 december 2019, ECLI:NL:HR:2019:1985. 
proces, komt het EHRM tot een schending van artikel 6 lid 3 sub c EVRM. ${ }^{32}$

De zaak Van de Kolk/Nederland biedt een sterk argument voor de vaststelling dat de verhouding tussen de uitwerking van het recht op verhoorbijstand zoals in Nederland uitgelegd in 2009 en de invulling die het EHRM daaraan geeft, uit het lood is geslagen. Volgens de Hoge Raad geldt het recht op verhoorbijstand voor iedere verdachte pas vanaf 22 december 2015 en kan hierop geen beroep worden gedaan met terugwerkende kracht. ${ }^{33}$ Door Van de Kolk/Nederland, waarin het EHRM een ruime uitleg geeft aan artikel 6 EVRM op dit punt, lijkt de uitleg van de Hoge Raad wat eng. ${ }^{34}$ In een recent door de Hoge Raad gewezen arrest staat deze kwestie centraal. ${ }^{35}$ Het eerste middel klaagt dat het hof de bij de FIOD afgelegde verklaringen uit 2007 heeft gebruikt voor het bewijs, terwijl verdachte geen verhoorbijstand heeft genoten, waardoor het recht op verhoorbijstand en daarmee artikel $6 \mathrm{EVRM}$ is geschonden. De Hoge Raad bespreekt het in paragraaf 2.2 besproken arrest van 22 december 2015 en benoemt hetgeen daaraan ten grondslag ligt. De Hoge Raad herhaalt hetgeen in dat arrest is overwogen omtrent de gevolgen die kunnen worden verbonden aan een verzuim in de nakoming van het recht op rechtsbijstand zoals dit na 22 december 2015 bestond. ${ }^{36}$ De Hoge Raad lijkt - onder verwijzing naar de conclusie van de A-G onder 17 tot en met $19-37$ tot de conclusie te komen dat verdachten ook vóor 22 december 2015 een recht op verhoorbijstand aan artikel 6 EVRM kunnen ontlenen. De vaststelling van de Hoge Raad dat het moment waarop het verhoor plaatsvond niet (meer) van belang is voor de vraag of rechtsbijstand had moeten worden verleend, brengt evenwel niet met zich dat verklaringen die zijn afgelegd zonder verhoorbijstand automatisch moeten worden uitgesloten van het bewijs. Indien geen dwingende redenen bestaan om het recht op verhoorbijstand te beperken, dient de procedure in zijn geheel te worden getoetst met inachtneming van onder meer de factoren uit Ibrahim e.a./Verenigd Koninkrijk. ${ }^{38}$

De A-G concludeert bij het arrest al dat de zaak $V a n d e$ Kolk/Nederland aanleiding gaf nader stil te staan bij de verhouding tussen de Nederlandse en Europese invulling van het recht op verhoorbijstand. Gelet op de rechtspraak van het EHRM betwijfelt de A-G of de rechtspraak van de Hoge Raad, waarin met name van belang is wanneer het verhoor heeft plaatsgevonden,

32. EHRM 28 mei 2019, ECLI:CE:ECHR:2019:0528JUD002319215, par. 34 (Van de Kolk/Nederland).

33. HR 6 september 2016, ECLI:NL:HR:2016:2018-2019; HR 12 maart 2019, ECLI:NL:HR:2019:341, NJ 2019/132.

34. Zie hierover ook Th.O.M. Dieben \& S.F.W. van 't Hullenaar, 'De zaak van Van de Kolk tegen Nederland', TPWS 2019/63, p. 152-155.

35. HR 17 december 2019, ECLI:NL:HR:2019:1985.

36. HR 17 december 2019, ECLI:NL:HR:2019:1985, r.o. 3.2.1-3.2.3.

37. Concl. A-G Hofstee 8 oktober 2019, ECLI:NL:PHR:2019:1018, bij HR 17 december 2019, ECLI:NL:2019:1985.

38. HR 17 december 2019, ECLI:NL:HR:2019:1985, r.o. 3.3. stand kan houden. ${ }^{39}$ Over een mogelijk beroep op (de Nederlandse implementatie van) de Richtlijn is de A-G kort: een klacht ter zake faalt vanwege het feit dat deze rechtsregels ten tijde van de FIOD-verhoren nog geen rechtskracht hebben.

Met betrekking tot de concrete zaak oordeelt de Hoge Raad, net als de A-G, dat de procedure in zijn geheel niet oneerlijk is verlopen, waardoor het hof niet tot een ander oordeel had kunnen komen dan dat het gebruiken van de verklaringen voor het bewijs geen schending oplevert van artikel 6 EVRM en geen bewijsuitsluiting hoeft te volgen. De klacht is daarmee in zoverre tevergeefs voorgesteld.

\subsection{Het Besluit}

In paragraaf 2.3 is het huidige wettelijk kader omtrent de rechtspositie van de raadsman tijdens het politieverhoor beschreven. Het EHRM kent in het arrest Soytemiz/Turkije een dermate ruime interpretatie toe aan artikel 6 lid 3 sub c EVRM dat de raadsman actief bijstand kan verlenen tijdens het politieverhoor. In hoeverre is de rechtspositie van de raadsman tijdens het politieverhoor in Nederland (nog) in overeenstemming met die uitleg?

De Nederlandse invulling van de rechtspositie van de raadsman staat op gespannen voet met de interpretatie van het EHRM van artikel 6 lid 3 sub c EVRM. Uit het Besluit lijkt niet zonder meer te volgen dat het de raadsman wordt toegestaan de verdachte actief bij te staan, op een wijze zoals in Soytemiz/Turkije is omschreven.

Het Besluit beperkt de raadsman op drie manieren in zijn handelen. Ten eerste mag de raadsman op grond van artikel 5 lid 1 Besluit zich slechts tot de verhoorder(s) richten. Het geven van direct advies aan zijn cliënt tijdens het politieverhoor, zoals het al dan niet gebruiken van het zwijgrecht, wordt hierdoor uitgesloten. Ten tweede is het de raadsman volgens artikel 5 lid 2 Besluit enkel toegestaan direct na aanvang en voor afloop van het politieverhoor vragen te stellen of opmerkingen te maken, zoals bedoeld in artikel 5 lid 1 Besluit. Die bepaling lijkt daarmee het stellen van vragen of maken van opmerkingen (aan de verhoorder!) tijdens het verhoor niet toe te laten. Ten derde beperkt artikel 6 Besluit de raadsman in die zin dat hij gedurende het politieverhoor slechts de verhoorder erop opmerkzaam mag maken dat de verdachte een hem gestelde vraag niet begrijpt, dat de verhoorder het pressieverbod niet in acht neemt en dat een verantwoorde voortzetting van het verhoor wordt verhinderd door de fysieke of psychische toestand van de verdachte. Andere punten mag hij, volgens het Besluit, blijkbaar niet aansnijden.

Indien de raadsman buiten de neergelegde bevoegdheden wil treden, is het indienen van een verzoek tot onderbreking van het politieverhoor ex artikel $28 \mathrm{~d}$ lid 1 Sv zijn enige optie. De verhoorder kan voorkomende

39. Concl. A-G Hofstee 8 oktober 2019, ECLI:NL:PHR:2019:1018, onder 20, bij HR 17 december 2019, ECLI:NL:HR:2019:1985. 
verzoeken echter betrekkelijk eenvoudig afwijzen, onder meer op de grond dat door het voldoen aan een herhaald verzoek de orde of voortgang van het politieverhoor wordt verstoord. Indien aan het verzoek tot onderbreking al een of meerdere verzoeken zijn voorafgegaan, wordt de kans groter dat een opsporingsambtenaar het verzoek als verstoring van de orde of voortgang aanmerkt. In dat geval bestaan voor de raadsman geen wettelijke mogelijkheden meer om in te grijpen, teneinde te realiseren dat de rechten van de verdachte worden gerespecteerd. Aangezien adviseren van de verdachte behoort tot het normale instrumentarium van de raadsman, is het niet onwaarschijnlijk dat de raadsman bij een afwijzing van het verzoek tot onderbreking van het politieverhoor buiten zijn bevoegdheden treedt. Op grond van artikel 8 Besluit kan dat betekenen dat hij - na eenmaal vruchteloos te zijn gewaarschuwd - uit de verhoorruimte kan worden gezet.

Het door het EHRM geformuleerde uitgangspunt dat het de raadsman wordt toegestaan actief bijstand te verlenen en dat hij mag interrumperen om te realiseren dat de rechten van de verdachte worden gewaarborgd, komt in het Besluit niet goed tot uitdrukking. Opmerking verdient dat artikel 8 lid 2 Besluit reguleert dat het verhoor na verwijdering van de raadsman pas kan worden voortgezet als de raadsman na enige tijd weer tot de verhoorruimte wordt toegelaten, de verdachte alsnog afstand doet van zijn recht op verhoorbijstand zoals bedoeld in artikel $28 \mathrm{a} \mathrm{Sv}$ of een andere raadsman ter vervanging beschikbaar is. Dat lijkt te suggereren dat de Nederlandse wetgever zich voor mogelijke schendingen van het recht op een eerlijk proces heeft willen behoeden. De verplichting niet te horen na verwijdering van de raadsman, brengt mee dat geen (bekennende) verklaring van de verdachte kan worden verkregen, zodat hiervan voor het bewijs geen gebruik kan worden gemaakt. Dit moet voorkomen dat in de strafprocedure een schending van het recht op rechtsbijstand plaatsvindt. Dat doet echter niets af aan het feit dat de invulling van de rechtspositie van de raadsman tijdens het politieverhoor, zoals thans in Nederland vormgegeven door artikel 28d $\mathrm{Sv}$ en het Besluit, wringt met het door het EHRM uitdrukkelijk geformuleerde uitgangspunt omtrent het recht op rechtsbijstand, zoals neergelegd in artikel 6 lid 3 sub c EVRM.

\section{Conclusie en aanbevelingen}

In deze bijdrage staat de vraag centraal hoe het Besluit omtrent de rechtspositie van de raadsman tijdens het politieverhoor zich verhoudt tot artikel 6 EVRM. Om deze vraag te beantwoorden, is de rechtspositie van de raadsman tijdens het politieverhoor uiteengezet vanuit nationaal (par. 2) en Europees (par. 3) perspectief. Vervolgens is een vergelijking gemaakt tussen die twee rechtssferen (par. 4).
Die vergelijking heeft geleid tot de vaststelling van een zekere onbalans tussen de Nederlandse invulling van de rechtspositie van de raadsman tijdens het politieverhoor en artikel 6 EVRM. Het in Soytemiz/Turkije uiteengezette uitgangspunt dat de raadsman de verdachte tijdens het politieverhoor actief mag bijstaan en mag interrumperen om een effectieve uitvoering van het recht op rechtsbijstand te realiseren, lijkt in het Besluit in mindere mate op de voorgrond te liggen. De in het Besluit besloten liggende beperkingen voor de raadsman tijdens het verhoor, zoals het zich niet direct mogen richten tot de verdachte, het slechts direct na aanvang of direct voor afloop van het verhoor stellen van vragen of maken van opmerkingen en het slechts in bepaalde gevallen wijzen op onregelmatigheden, versterken die gedachte.

Gelet op bovenstaande conclusie kan worden gesteld dat het Besluit, gelet op het feit dat Europese regelgeving en rechtspraak slechts minimumwaarborgen bieden, te rigide is geformuleerd. Om tegemoet te komen aan de invulling van artikel $6 \mathrm{EVRM}$ door het EHRM, is het wenselijk de bepalingen in het Besluit (meer) in lijn te brengen met de uitspraak Soytemiz/Turkije. Gedacht kan worden aan het expliciet herhalen van wettelijke voorwaarden voor de verhorend ambtenaar, zoals het in acht nemen van het zwijgrecht en pressieverbod. Anderzijds kan ook een aantal beperkende voorwaarden worden aangepast. In dat geval kan worden gedacht aan het schrappen van de voorwaarde dat vragen direct na aanvang of voor afloop mogen worden gesteld. Op die wijze blijft enerzijds een zekere nadruk op de voortgang van het politieverhoor bestaan, maar wordt anderzijds de raadsman ruimte geboden om actief bijstand te verlenen. Eventuele klachten over het optreden van de raadsman tijdens het verhoor zouden in een klachtprocedure bij de Orde van Advocaten kunnen worden behandeld.

De bestaande onbalans van de bepalingen in het Besluit met de invulling van artikel 6 EVRM door het EHRM plaatst vraagtekens bij de juridische waarde van het Besluit. Adequate rechtsbescherming lijkt niet te worden gediend door het slechts toelaten van een raadsman bij het politieverhoor. De verdediging moet ook daadwerkelijk kunnen worden gevoerd. 